DOI: https://doi.org/10.24127/ajpm.v10i1.3429

\title{
DISCOVERY AND CORE LEARNING MODEL TOWARD CREATIVE THINKING VIEWED FROM LOGICAL MATHEMATICAL INTELLIGENCE
}

\author{
Veronika Yusnita Andriani Prastika ${ }^{1}$, Riyadi $^{2}$, Siswanto $^{3}$ \\ 1,2,3 Mathematics Education, Universitas Sebelas Maret, Surakarta, Indonesia \\ *Corresponding author. Madiun, Indonesia \\ E-mail: $\quad \underline{\text { veronikaandriani5@gmail.com }}^{\left.{ }^{*}\right)}$ \\ riyadifkipuns@gmail.com $^{2)}$ \\ sis.mipa@staff.uns.ac.id $^{3)}$
}

Received 26 December 2020; Received in revised form 05 March 2021; Accepted 29 March 2021

\begin{abstract}
This research aims to 1) which learning model that supports students' creative thinking ability whether discovery, CORE, or conventional learning model, 2) which model that supports creative thinking ability the most to high, moderate, and low level students, 3) know if there is interaction between learning model and students' logical mathematical intelligence, and creative thinking ability. This is a quasi-experimental research with the population of eighth graders of junior high schools in Madiun Regency. The research design used a group pretest-posttest control design. The sample was determined using stratified cluster random sampling. This research uses two-way unequal ANOVA. This research concluded that 1) students' creative thinking skill is developed better using Discovery than CORE and conventional learning model, 2) students with high logical mathematical intelligence have higher creative thinking ability than those with moderate and low logical mathematical intelligence,3) there is no interaction between learning model and logical mathematical intelligence with creative thinking ability.
\end{abstract}

Keywords: Creative thinking; learning model; logical mathematical intelligence.

\begin{abstract}
Abstrak
Tujuan dari penelitan ini untuk mengetahui 1) model pembelajaran manakah yang memberikan kemampuan berpikir kreatif yang lebih antara model pembelajaran discovery learning, CORE atau konvensional, 2) manakah yang memberikan kemampuan berpikir kreatif yang lebih baik siswa yang memiliki kecerdasan logis matematis tinggi, sedang, atau rendah, 3) apakah terdapat interaksi antara model pembelajaran dan keceredasan logis matematis dengan kemampuan berpikir kreatif siswa. Metode yang digunakan pada penelitian adalah eksperimen semu, dengan populasi siswa kelas VIII SMP N Se-Kabupaten Madiun. Desain penelitian menggunakan group pretest-posttest control design Pemilihan sampel dengan menggunakan stratified cluster random sampling. Teknik analisis penelitian ini menggunakan anava dua jalan dengan sel tak sama. Kesimpulan pada penelitian ini 1) kemampuan berpikir kreatif siswa yang kenai model discovery learning lebih baik daripada model pembelajaran CORE dan konvensional, 2) Kemampuan berpikir kreatif siswa yang memiliki kecerdasan logis matematis tinggi lebih baik daripada siswa yang memiliki kecerdasan logis matematis sedang dan rendah, , 3) tidak ada interaksi antara model pembelajaran dan kecerdasan logis matematis dengan kemampuan berpikir kreatif.
\end{abstract}

Kata kunci: Berpikir kreatif; kecerdasan logis matematis; model pembelajaran. 
DOI: https://doi.org/10.24127/ajpm.v10i1.3429

\section{INTRODUCTION}

Mathematics is one of the essential fields of science, and a basic of other fields of sciences. Mathematics also has an important role in developing education and technology nowadays. In this 4.0 era, students are expected to master high level thinking skills. Creative thinking ability is one of high level thinking skill. Creative thinking is the ability to provide various interpretations in solving problems (Ulfah et al., 2017). There are three components of creative thinking ability: fluency, flexibility, and novelty.

The research conducted was the preliminary research related to creative thinking and obtained the result in the indicator of fluency with the average score of 55,27; flexibility is 47,23; and novelty is 40,11 . This happens since students were not able to find other ways to solve problems, provide various answers, and answer the directions in sequence. This is in line with Hanipah (2018) that students' ability in providing suitable ideas and producing various ways in solving problems are categorized as good creative thinking ability.

Students' creative thinking ability is in a low category. This is supported by the interview with some Mathematics teachers who stated that there were no questions that lead students to have creative thinking ability; most of them tend to do answer the common questions using the directed steps. Teachers still used that conventional method. They had not applied a learning model that lead students to be active in learning and manage their cognitive thinking ability so that they will create new creative ideas.

Therefore, it is important to change the learning model in students learning process in order to develop their creative thinking ability. This agrees with Fitriyah (2017) that most Mathematics teachers explain the material in a conventional way, so there are no students' actively involved in the activity. Therefore, two learning models that have the potential to make students actively take part in the learning process and train their thinking ability is discovery and CORE learning model (connecting, organizing, reflecting, dan extending).

Discovery learning model is a learning method based on students' own discovery (Sihombing, 2017). The process is the main key in developing students' thinking ability and the cognitive process is discovery. This depends on how the learning process runs (Sahara \& Mardiyana, 2018). According to Suhana (2014), this learning model can discover understanding in students' own way using their abilities in finding information. The characteristic in this model is exploring and solving problems to create and generalize science; the activity to combine new and old knowledge, and based on students-centered (Putriani et all., 2018).

This is supported by the research of the result from Fitriya (2017) which stated that discovery learning model gives a positive effect on students learning output. According to Werdiningsih (2019), Discovery Learning method can improve students' creativity, participation, and confidence in the learning process at school.

CORE (connecting, organizing, reflecting, dan extending) learning model emphasizes discussion in groups that can influence students' knowledge development (Mafthukhah, 2017). According to Virginiawaty (2019) there 
are four aspects: connecting is an activity that connects old and new information, organizing is an activity that organizes ideas to understand, reflecting is the process of thinking, organizing, and penetrating information obtained, extending is an activity that uses, expands, and discovers new things. This model is emphasized to students by involving thinking activity through organizing data obtained (Karyati, 2020). This is in line with Arifah (2016) that creative thinking supported by CORE learning model is completed and gives a significant impact on students' learning process.

Besides the learning model, there are factors that influence students' creative thinking ability. One of which is logical mathematical intelligence. This is the intelligence related to Mathematics since it involves reasoning, numbers, and mathematical ability in solving a problem (Arismayani, 2015). According to Safranj (2016), a person with this ability will pay close attention to procedures and tend to be systematic based on reasoning. Students with high logical mathematical ability will be able to count systematically using various mathematical skill, and can analyze situations (Arum, 2018).

This research aims to 1) figure out which learning model supports students' creative thinking ability whether discovery, CORE, or conventional learning model, 2) find out which model that supports creative thinking ability the most to high, moderate, and low level students, 3) know if there is an interaction between learning model, and students' logical mathematical intelligence and creative thinking ability.

\section{METHODS}

This is an experimental research with the population of eight graders of junior high schools in Madiun Regency in the academic year of 2019/2020. The research design is Quasi Experimental Design. The experimental research design used in this study was the Group Pretest-Posttest Control Design. The technique of sample selection is Cluster Random Sampling using the score of the National Examination of Mathematics in Madiun Regency in 2019. The population was divided based on the school rank from low, moderate, to high. Then, each group was decided randomly in a school that was used as a sample through lottery. It was obtained 3 schools: State Junior High School of 1 Geger, State Junior High School of 1 Jiwan, and State Junior High School of 2 Wungu. In each chosen school, it was obtained 3 classes randomly with a lottery as a class of experiment 1 (Discovery Learning), experiment 2 (CORE learning model), and control class (conventional learning model).

Then, three classes of each school were chosen as sample. The subjects in this research were 295 students with 195 in the experimental class, consisting of 98 students using the discovery learning model and 97 students using the CORE learning model, then for the control class consisting of 100 students. Then categorized into high, medium, and low which are presented in Table 1.

Table 1. The level of description in each learning model

\begin{tabular}{cccc}
\hline The Category of & \multicolumn{2}{c}{ Group } & \\
\cline { 2 - 3 } $\begin{array}{c}\text { Logical } \\
\text { Mathematical } \\
\text { Intelligence }\end{array}$ & Experiment & Control & Total \\
\hline High & 69 & 19 & 88 \\
Moderate & 80 & 49 & 129 \\
Low & 46 & 32 & 78 \\
Total & 195 & 100 & 295 \\
\hline
\end{tabular}


Table 1 shows that students in the high level of logical mathematical intelligence is 88 , those in the moderate level is 129 , and those in the low level is 78 .

The data collection method used in this research is a test. The questions were in the form of essay test. This test was used to obtain creative thinking ability data before and after treatment. Then the mathematical logical intelligence questions were in the form of multiple-choice questions. This test was used to obtain the students' logical mathematical intelligence after treatment.

After the test created, the validation test was conducted to some experts. Then, the test was experimented to eight graders in two schools out of the research sample to know the difficulty index, distinguishing power, and reliability. Based on the result of analysis of creative thinking instrument, it was obtained 2 questions, and it was obtained 27 questions for logical mathematical intelligence. The result of pre-test and post-test average score of creative thinking is presented in Figure 1.

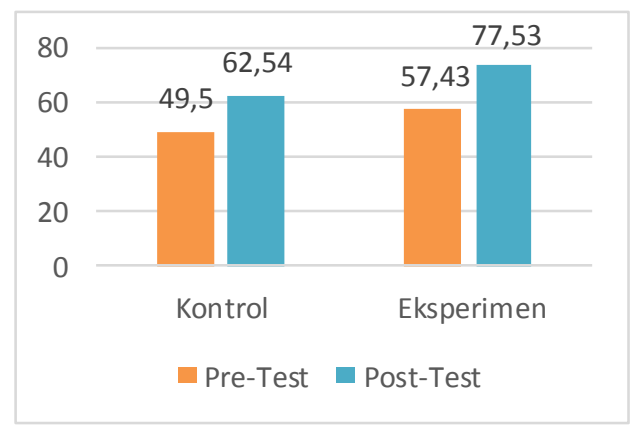

Figure 1. Students' average score of pre-test and post-test.

This research uses two-way unequal ANOVA. The Prerequisite test used in research analysis is normality test with Liliefors method and homogeneity test with Barlett method.

\section{RESULTS AND DISCUSSION}

The analysis of research data summary will be presented in the following table started from the description of variable average, normality test, homogeneity test, variance analysis result, to comparison test. After the data was processed, it was obtained the marginal average description for learning models and logical mathematical intelligence presented in Table 2.

Table 2. The description of the average of each variable.

\begin{tabular}{ccccc}
\hline \multirow{2}{*}{ Model (A) } & \multicolumn{3}{c}{ Logical Intelligence (B) } & \multirow{2}{*}{$\begin{array}{c}\text { Marginal } \\
\text { Average }\end{array}$} \\
\cline { 2 - 4 } & High & Moderate & Low & 80.65 \\
DL & 85.29 & 81.74 & 74.87 & 74.40 \\
CORE & 79.82 & 73.74 & 69.66 & 62.54 \\
PL & 67.84 & 62.85 & 56.90 & \\
Marginal average & 77.65 & 72.57 & 67.14 & \\
\hline
\end{tabular}

Based on Table 2, the marginal average obtained for Discovery Learning model was 80,65, CORE learning model was 74,40, and conventional learning model was 62,54. The average score of high logical mathematical intelligence was 77,65 , moderate logical mathematical intelligence was 73,57, and low logical mathematical intelligence was 67,14 . Then, the normality test is presented in Table 3.was conducted to figure out 
DOI: https://doi.org/10.24127/ajpm.v10i1.3429

whether the sample came from the normal distribution population or not.
The result of normality test can be seen in table 3.

Table 3. The result of normality test

\begin{tabular}{llcccc}
\hline \multicolumn{1}{c}{ Data } & Group & $\boldsymbol{L}_{\boldsymbol{o b s}}$ & $\boldsymbol{L}_{(\mathbf{0}, \mathbf{0 5} ; \boldsymbol{n})}$ & Test Determination & Conclusion \\
\hline Learning & Discovery & 0,086 & 0,089 & $\mathrm{H}_{0}$ is not rejected & Normal \\
Model & Learning & & & & \\
& CORE & 0,079 & 0,090 & $\mathrm{H}_{0}$ is not rejected & Normal \\
& Convensional & 0,065 & 0,089 & $\mathrm{H}_{0}$ is not rejected & Normal \\
Logical & High & 0,065 & 0,094 & $\mathrm{H}_{0}$ is not rejected & Normal \\
Mathematical & Moderate & 0,072 & 0,078 & $\mathrm{H}_{0}$ is not rejected & Normal \\
Intelligence & Low & 0,089 & 0,100 & $\mathrm{H}_{0}$ is not rejected & Normal \\
\hline
\end{tabular}

The normality test was conducted to figure out whether the sample came from the normal distribution population or not. Based on table 3, it can be described that the result of normality test is $L_{o b s} \notin D K=\left\{L \mid L>L_{0,05 . n}\right\}$. Therefore, it can be concluded that the sample comes from the normal distribution population.

Another prerequisite test after normality test is homogeneity test. Furthermore, a homogeneity test will be carried out to determine whether the population has a homogeneous variance. The result of homogeneity test is presented in Table 4.
Table 4. The result of homogeneity test

\begin{tabular}{lcc}
\hline & $\mathfrak{x}_{\text {obs }}^{\mathbf{2}}$ & $\mathfrak{x}_{\mathbf{0}, \mathbf{0 5} \mathbf{2}}^{\mathbf{2}}$ \\
\hline $\begin{array}{l}\text { Creative Thinking } \\
\text { Logical }\end{array}$ & 0,569 & 5,991 \\
$\begin{array}{l}\text { Mathematical } \\
\text { Intelligence }\end{array}$ & 4,558 & 5,991 \\
\hline
\end{tabular}

Based on table 4, it obtains $x_{o b s}^{2}<x_{0,05 ; 2}^{2}$, which means that $H_{0}$ is not rejected or the variances in the population are homogeneous. Then, after the prerequisite test was fulfilled, it was continued with the two-way ANOVA to find out whether the variable gives an effect on creative thinking or not presented in table 5 .

Table 5. The result of unequal two-way ANOVA

\begin{tabular}{crrrrrc}
\hline Source & \multicolumn{1}{c}{ JK } & dk & RK & Fobs & Ftab & Determination \\
\hline Model (A) & 16611.19 & 2.00 & 8305.60 & 42.93 & 3.00 & $H_{0}$ is rejected \\
KLM (B) & 5425.41 & 2.00 & 2712.70 & 14.02 & 3.00 & $H_{0}$ is rejected \\
Interaction (AB) & 82.93 & 4.00 & 20.73 & 0.11 & 2.37 & $H_{0}$ is not rejected \\
Galat & 55330.93 & 286.00 & 193.46 & & & \\
Total & 77450.46 & 294.00 & & & & \\
\hline
\end{tabular}

Based on the result of ANOVA test in table 5, it obtains:

(1) The result of learning model factor obtains $\quad F_{o b s}=42,93>F_{t a b}-$ 3,00 which means that $H_{0}$ is rejected. Therefore, it can be concluded that there is a different effect of between learning model with creative thinking ability.

(2) The result of logical mathematical intelligence obtains $F_{\text {obs }}=$ $14,02>F_{t a \text { Q }}=3,00$ which means that $H_{0}$ is rejected. Therefore, it can be concluded that there is a 
DOI: https://doi.org/10.24127/ajpm.v10i1.3429

different effect between high, moderate and low logical mathematical intelligence with creative thinking ability.

(3) The result of learning model factor and logical mathematical intelligence obtains $F_{\text {obs }}=0,11>$ $F_{\text {tab }}=2,37$ which means that $H_{0}$ is not rejected. Therefore, it can be concluded that there is an interaction between learning model and logical mathematical intelligence with creative thinking ability.

Since factor A (learning model) and factor B (logical mathematical intelligence) were rejected, ANOVA post-test was done through inter-lines comparison test and inter-column comparison test presented in table 6 .

Table 6. The result of double comparison test

\section{Double Line Comparison}

\begin{tabular}{cccc}
\hline $\boldsymbol{H}_{\mathbf{0}}$ & $\boldsymbol{F}_{\boldsymbol{o b s}}$ & $\mathbf{2 F}_{\mathbf{0 , 0 5 ; 2 ; 2 9 5}}$ & Test Determination \\
\hline$\mu_{1 .}=\mu_{2 .}$ & 9.86 & 6.00 & $\mathrm{H}_{0}$ is rejected \\
$\mu_{1 .}=\mu_{3 .}$ & 83.94 & 6.00 & $\mathrm{H}_{0}$ is rejected \\
$\mu_{2 .}=\mu_{3 .}$ & 35.78 & 6.00 & $\mathrm{H}_{0}$ is rejected \\
\hline
\end{tabular}

Double Column Comparison

\begin{tabular}{cccc}
\hline $\boldsymbol{H}_{\mathbf{0}}$ & $\boldsymbol{F}_{\boldsymbol{o b s}}$ & $\mathbf{2 F}_{\mathbf{0 , 0 5} \mathbf{2} ; \mathbf{2}<\mathbf{5}}$ & Test Determination \\
\hline$\mu_{.1}=\mu_{.2}$ & 6.96 & 6.00 & $\mathrm{H}_{0}$ is rejected \\
$\mu_{.1}=\mu_{.2}$ & 23.58 & 6.00 & $\mathrm{H}_{0}$ is rejected \\
$\mu_{.2}=\mu_{.3}$ & 7.40 & 6.00 & $\mathrm{H}_{0}$ is rejected \\
\hline
\end{tabular}

After the double line comparison test presented in table 6 it is, determined that $\mathrm{H}_{0}$ is rejected. In other words, there is a difference between discovery and CORE learning model toward creative thinking ability. Then, by seeing the marginal average in the discovery learning, the average score is 80,65 . The CORE learning model has an average score of 74,40 and conventional learning model has an average score of 62,54 . Therefore, it can be concluded that discovery learning model develop students' creative thinking ability more than CORE and conventional learning model, and CORE learning model gives a positive impact on students' creative thinking ability more than conventional learning model.

Next, double column comparison test is presented in table 6 and shows that $\mathrm{H}_{0}$ is rejected. It can be said that there is a difference between high, moderate and low logical mathematical intelligence toward creative thinking ability. By paying attention on marginal average about high logical mathematical intelligence obtains 77,65, moderate 72,57, and low 67,14. It can be concluded that students with high logical mathematical intelligence have better creative thinking ability than moderate and low one, and students with moderate logical mathematical intelligence have better creative thinking ability than the low one.

The result of this research showed that students' creative thinking using discovery learning model is better than CORE and conventional learning model, and CORE learning model is better than conventional learning model. This is supported by the field observation that students with discovery 
learning model tend to be more active, even able to find solutions well in learning activities. Students' activity was divided into some groups, then they were given LKPD based on learning material. As the learning process was conducted, the classroom environment became more active. Then, there was questions answers activity and sharing opinion when teacher delivered learning material. This is so much different with the conventional learning model where students were passive when teacher presented learning material.

This is in line with Sihombing (2017) that discovery learning model gives a positive impact on students' learning output because this model supports students' curiosity, active participation in gaining information from various resources to solve problems, and this activity also combine students' new and old knowledge. In addition, Virginiawaty (2019) stated that CORE learning model is a learning process that emphasizes students' thinking ability to combine, organize, comprehend, organize, and develop information.

In addition, the research found that students with high logical mathematical intelligence had better creative thinking ability than those who had moderate and low logical mathematical intelligence. This happens since high logical mathematical intelligence students had the ability to think mathematically and procedurally, and able to build the thinking framework in solving problems that affect students' learning experience.

The ability to calculate in the form of numbers, logic, and reason will be revealed when they create a solution. Therefore, creativity and attractiveness towards Mathematics will influence students' creative thinking ability. This is different with the students who have moderate and low logical mathematical intelligence. They tend to be passive in group work, and only follow the learning process without having eager to solve problems. In other words, it influences their creative thinking ability.

That is in line with Azinar (2020) that this intelligence develop someone's rational thinking, reasoning, and logic. A person who is able to count, operate the numbers correctly and quickly, and understand material comprehensively belongs to high logical mathematical intelligence (Arum D, 2018). Someone with good logical mathematical intelligence will be able to understand material and manage it logically (Milsa 2018). According to Supardi (2014), logical mathematical intelligence gives a significant positive impact on students' learning process. This is in line with Milsan (2018), that logical mathematical intelligence gives a positive impact on students.

The result also found that there was no interaction between learning model and logical mathematical intelligence. This happens due to some factors during the data collection process: the mismatch between students' answers (sample) with the students' characteristics, the time limit in answering the questions related to the logical mathematical intelligence.

The result of the research is strongly supported by Fitriya (2017), which stated that discovery learning model gives a positive effect. According to Muslim (2016), discovery learning model can improve students' creative thinking ability. This is also in line with Mawaddah (2015) that discovery learning model can develop students' creative thinking ability in learning. Next, Cintia, N, et al. (2018) showed 
that discovery learning model can improve students' creative thinking ability. Based on Werdiningsih (2019), discovery learning model can improve students' creativity, participation, and confidence in joining learning process activities at school.

This research is theoretically expected to be able to give a contribution on the development of Mathematics learning, especially related to discovery and CORE learning model. The result of the research is expected to give information related to the use of discovery and CORE learning model on creative thinking ability, provide effective and innovative learning alternative to make students easy to learn.

\section{CONCLUSION AND SUGGESTION}

Based on the research conducted, it can be concluded that, (1) students' creative thinking ability with discovery learning model is better than CORE and conventional learning model, (2) students with high logical mathematical intelligence have better creative thinking ability than those who have moderate and low logical mathematical intelligence. (3) there is no interaction between learning model and logical mathematical intelligence with creative thinking ability.

For the next researches, this research becomes the consideration on the importance of discovery and CORE learning model in delivering learning material to make students easier to understand the material. In addition, the next researchers are better to use other innovative learning models that are able to support students' creative thinking ability. This research only observed students' logical mathematical intelligence. It is suggested that the next researches observe other variables such as mathematics skill, mathematics dispositions, and others.

\section{REFERENCES}

Arifah, Y N., Rochmad., \& Sugiman. (2016). Keefektifan Model Pembelajaran CORE Berbantuan Strategi Studi Kasus Terhadap kemampuan Berpikir Kreatif Siswa SMP. Unnes Journal of Mathematics Education Research, 5(2), 124-130. https://doi.org/10.15294/ujme.v5i2. 11737

Arismayani, N., Yusuf, T., \& Latuconsina, N. (2015). Pengaruh Pendekatan Pembelajaran dan Kecerdasan Logis Matematis Terhadap Hasil Belajar Matematika Siswa Kelas VIII SMP Negeri 1 Polong Bengkeng Utara Kabupaten Takalar. Matematika Dan Pembelajaran, 3(2), 120-148. https://doi.org/10.24252/mapan.20 $15 v 3 \mathrm{n} 2 \mathrm{a} 1$.

Arum, D., Kusmayadi, T., \& Pramudya, I. (2018). Student's logicalmathematical intelligence profile. J. Phys.: Conf. Ser.1008 012071. http://dx.doi.org/10.1088/17426596/1008/1/012071

Azinar, J ., Munzir, S., \& Bahrun. (2020). Students' LogicalMathematical Intelligence Through The Problem-Solving Approach. Journal of Physics: Conf. Series 1460012024.

Cintia, N I., Kristin, F., \& Angugraheni, I. (2018). Penerapan Model Pembelajaran Discovery Learning untuk Meningkatkan Kemampuan Berpikir Kreatif dan Hasil Belajar Siswa. Prefektif Ilmu Pendidikan, 32(1). 69-77. https://doi.org/10.21009/PIP.321.8

Fitriyah, A., Murtadlo, A., \& Warti, R. (2017). Pengaruh Model 
DOI: https://doi.org/10.24127/ajpm.v10i1.3429

\begin{abstract}
Pembelajaran Discovery Learning Terhadap Hasil Belajar Matematika Siswa Man Model Kota Jambi. Jurnal Pelangi, 9(2), 108-112.

http://dx.doi.org/10.22202/jp.2017. v9i2.1898
\end{abstract}

Hanipah, N., Yuliani, A., \& Maya, R. (2018). Analisis Kemampuan berpikir kreatif matematis siswa MTs pada materi lingkaran. AKSIOMA, 7(1), 80-86.

Mafthukhah, N. A., Nurhalim, K., \& Isnarto (2017). Kemampuan Berpikir Kreatif dalam Pembelajaran Model Connecting Organizing Reflecting Extending Ditinjau dari Kecerdasan Emosional. Journal of Primary Education, 6(3), 267-276. https://doi.org/10.15294/jpe.v6i3.2 1141

Mawaddah, N. (2015). Model pembelajaran discovery learning dengan pendekatan metakognitif untuk meningkatkan metakognisi dan kemampuan berpikir kreatif matematis. Unnes Journal of Mathematics Education Research, 4(1), 10-17.

Milsan, A., \& Wewe, M. (2018). Hubungan antara Kecerdasan Logis Matematis dengan Hasil Belajar Matematika. Journal of Education Technology, 2(2), 6572.

http://dx.doi.org/10.23887/jet.v2i2. 16183

Muslim, S. R. (2016). Kontribusi Penggunaan Model Discovery Learning Terhadap Kemampuan Berpikir Kreatif Matematik Peserta Didik. Penelitian Pendidikan Dan Pengajaran Matematika, 2(1), 6774.

https://doi.org/10.37058/jp3m.v2i1 .158
Putriani, D., \& Rahayu, C. (2018). The Effect of Discovery Learning Model Using Sunflowers in Circles on Mathematics Learning Outcomes. International Journal of Trends in Mathematics Education Research, 1, 22-25.

Safranj, J. (2016). Logical Mathematical Intelligence in Teaching as a Second Language. Social and Behavioral Sciences, 232, 75-82. https://doi.org/10.1016/j.sbspro.20 16.10.019

Sahara R., Mardiyana., \&Saputro, D. (2018). Discovery learning with SAVI approach in geometry learning. Journal of Physics: Conf. Series $\quad 1013 \quad 0121125$ https://doi.org/10.1088/17426596/1013/1/012125.

Sari, E.P., \& Karyati. (2020). CORE (Connecting, Organizing, Reflecting \& Extending) Learning Model to Improve The Ability Of Mathematical Connections. Journal of Physics: Conf. Series 1581 012028. https://doi.org/10.1088/17426596/1581/1/012028.

Sihombing, H. (2017). The Effect Discovery Learning Model to Student Mathematical Concept Mastery. Journal of Research \& Method in Education, 7(5), 18-23.

Suhana, C. (2014). Konsep Strategi Pembelajaran (Edisi Revisi). Bandung: Refika Aditama.

Supardi. (2014). Peran Kedisiplinan Belajar Dan Kecerdasan Matematis Logis Dalam Pembelajaran Matematika. Jurnal Formatif, 4(2), 80-88.

http://dx.doi.org/10.30998/formatif .v4i2.142

Ulfah, U., Prabawanto S., \& Jupri, A. (2017). Student's Mathematical 
DOI: https://doi.org/10.24127/ajpm.v10i1.3429

Creative Thinking Through Problem Posing Learning. IOP Conf. Series: Journal of Physics: Conf. Series 89501209. https://doi.org/10.1088/17426596/895/1/012097.

Virginiawaty, K. K., \&Saragih, M. J. (2019). The implementation of connecting, organizing, reflecting, extending to improve mathematics connection grade 11 science student at one of Christian Senior High School in Rantepao. Journal of Physics: Conf. Series 1307 012011

https://doi.org/10.1088/17426596/1307/1/012011.

Werdiningsih, C. E. (2019). Pengaruh Model Pembelajaran Discovery Learningterhadap Kemampuan Berpikir Kreatif pada Siswa Kelas VII SMP Bekasi. Diskusi Panel Nasional Pendidikan Matematika 2019, 399-404. 